Journal of Science Education Research

Journal homepage: www.journal.uny.ac.id/jser

JSER

\title{
The Effectiveness of Student Team Achiement Divisions (STAD) Cooperative Learning In Science Learning On Analysis Skills and Social Skills
}

\author{
Yunita Aryanti ${ }^{1}$, Eko Widodo ${ }^{2}$ \\ ${ }^{1}$ Department of Science Education, Faculty of Mathematics and Natural Sciences, Universitas Negeri Yogyakarta. \\ Jalan Colombo No. 1, Yogyakarta 55281, Indonesia \\ * Corresponding Author. Email: yunita.aryanti2016@student.uny.ac.id
}

\section{Keywords:}

\begin{abstract}
The purpose of this study is (1) to know the effectiveness of the application of STAD cooperative learning to the ability of analysis, to know the effectiveness (2) the application of the STAD type of cooperative learning to the social skills of students in science subjects, and (3) to know the effectiveness of the application of type cooperative learning STAD on students' analytical skills and social skills of students in natural science subjects. This type of research is a quasi-experimental design with a non-equivalent control group. The population in this study were all class VII SMP Negeri 4 Wonosari, amounting to 5 classes. Sampling was done by cluster random sampling technique. The sample of this study, namely class VII A as an experimental class and class VII B as a control class. Research instruments in the form of (1) multiple choice question sheets to determine students' analytical skills, (2) social skills questionnaire sheets, and (3) observation sheets of social skills used during learning. Hypothetical test is parametric through the MANOVA test, followed by the calculation of Cohen's effect size. The results showed that (1) the STAD type cooperative learning model was effective in increasing students' ability to analyze science in science subjects, (2) the STAD type cooperative learning model was effective in increasing the social skills of students in science subjects, and (3) the cooperative learning model STAD type is effective for improving students' analytical skills and social skills in natural science subjects.
\end{abstract}

C2020 JSER. Yogyakarta State University

\section{INTRODUCTION}

In order to develop curriculum education in Indonesia, there have been several changes and revisions. It aims to adjust the ability of students with the demands of the times. The Indonesian education system currently uses the 2013 Curriculum system as a replacement for the Education Unit Level Curriculum (SBC). In it there is a scientific approach to the direct instruction learning model. In practice, a teacher according to (Arif, 2015: 250-251) needs to design minimal learning by preparing things; 1) develop learning objectives, 2) develop learning activities, 3) choose the right learning methods and techniques, 4) choose the right media, 5) choose teaching materials that are in accordance with the achievement of competencies, 6) choose the right learning resources, and 7) determine the assessment instruments that can measure students' competencies.

The 2013 curriculum demands the activeness of students is no exception in science learning. Science is a collection of knowledge through natural study objects that are studied systematically. Science learning not only provides theory for students but also provides real experience about what science is. The implementation of natural science learning cannot be separated from the application of methods during class. The learning method is one of the curriculum elements and is used in the learning process. The function of 
the learning method is to help students through learning, teaching materials, educators, etc. (Sudjana, 2007: 8).

However, Based on the results of observations of researchers in SMP N 4 Wonosari, it is known that it has used the 2013 curriculum which should be learning centered on students not teachers, but in reality the learning process is more centered on teachers (teacher center). The use of the 2013 curriculum is still dominant in teachers, this can be seen from the learning process that although it uses Student Worksheet, the lecture method is still applied in the explanation of the material. Thus, students easily feel bored and lack enthusiasm in participating in science learning.

The lack of social skills is shown when the teacher or other students make presentations in front of the class, students tend to be busy and have discussions that have nothing to do with science lessons, so an impression of not being enthusiastic in learning arises. The students' low analytical skills are shown when the teacher gives a case related to C4 (Analysis) students tend to become inactive in learning and there are no students who answer questions from the teacher. This is known from the number of students who have not exceeded the minimum completeness criteria (MCC) score, which is 75. The following data shows the results of the Final Semester Assessment (FSA), grade VII students of Junior High School 4 Wonosari at 2019. Table 1. FSA grades VII of Junior High School 4 Wonosari in the 2019/2020

Class $\quad$ Average of FSA in semester 1

\begin{tabular}{cc}
\hline VII A & 48.63 \\
\hline VII B & 40.14 \\
\hline VII C & 38.03 \\
\hline VII D & 37.75 \\
\hline VII E & 39.54
\end{tabular}

(Source: Final Semester Assessment 1, Junior High School 4 Wonosari)

One learning model that can improve students' social skills is the STAD cooperative type. The heterogeneity of the zoning system becomes a value added opportunity for success in learning using learning models using cooperative type STAD the more diverse variations in academic ability of students, the more possible it is possible to form teamwork. STAD is one type of cooperative learning. The model involves several small groups of students with different academic levels. The small group requires students to work together in completing the learning objectives (Miftahul Huda,
2015: 201). Through STAD type cooperative learning models students' social skills can be formed by discussion between friends of mutual tolerance and respect for the opinions of others.

According to Gull (2015: 247) the reason for cooperation being the main pathway in education is one of them because the use of STAD cooperative learning is able to improve student learning outcomes and be able to develop relationships between groups. More effective STAD type cooperative learning models to improve cognitive learning outcomes as measured by students have analytical skills in science learning because STAD cooperative models are seen as active learning processes, because students will learn more through work processes in groups and knowledge sharing. By using an interesting learning model one of which is the STAD cooperative model is expected to improve the quality of students to be better, especially on analytical skills and social skills.

Based on this description, this study focuses on the STAD cooperative learning model in learning of the analytical skills and social skills of science which aims to analyze: The purpose of this study is (1) to determine the effectiveness of the application of the STAD type of cooperative learning to the analytical skills, know the effectiveness (2) the application of STAD type cooperative learning to students 'social skills of students in science subjects, and (3) knowing the effectiveness of the application of STAD type cooperative learning to students' analytical skills and social skills of students in science subjects.

\section{RESEARCH METHODS}

This type of research used in this study is a quasi experiment with a non-equivalent control group design. This design has two classes consisting of the control class and the experimental class as follows.

Table 2. Non-Equivalent Control Group Design Class Pre Test Treatmen (Posttest)

\begin{tabular}{llll}
\hline Experimental & $\mathrm{O}_{1}$ & $\mathrm{X}_{1}$ & $\mathrm{O}_{2}$ \\
\hline Control & $\mathrm{O}_{3}$ & $\mathrm{X}_{2}$ & $\mathrm{O}_{4}$
\end{tabular}

(Sugiyono, 2015: 116)

Explanation :

$\mathrm{O} 1=$ Pretest on the experimental group

$\mathrm{O} 2=$ Posttest of the experimental group

$\mathrm{O} 3=$ Pretest the control group

$\mathrm{O} 4=$ Posttest to the control group

$\mathrm{X} 1$ = Treatment of experimental groups (using

STAD type cooperative learning models)

$\mathrm{X} 2$ = Treatment of control groups (using the direct instruction learning model) 
Yunita Aryanti, Eko Widodo / JSER 2020, 4(1), 24

The population in this study were all class VII Junior High School 4 Wonosari 2019/2020 school year a number of 5 classes, namely classes VII A, VII B, VII C, VII D, and VII E. Sampling is done by cluster random sampling technique, which is random sampling of groups, not from individuals, but individual groups (clusters). This sample was taken with the condition that the population is homogeneous and has a normal distribution using the value of Final Semester Assessment 1 Natural Sciences class VII A to VII A. The draw results obtained class VII A as an experimental class and class VII B as a control class.

The independent variable in this study is the learning model used in the experimental class and the control class. In the experimental class using the STAD cooperative learning model. Whereas the control class uses a direct learning model (direct instruction). While the dependent variable in this study is the ability of student analysis and social skills in learning science. Then the control variables in this study include: (1) classes taken from the same level, (2) learning material provided, (3) the amount of time allocation during learning, (4) the same test instruments used, (5) the number of meeting hours, (6) the same teaching teacher, and (7) the same subject matter.

The instrument used was a learning device and data collection instrument. Learning instrument instruments include the Learning Implementation Plan (RPP) and the Student Worksheet. While the data collection instruments, namely 1) multiple choice question sheets to determine students' analytical skills, (2) social skills questionnaire sheets, and (3) observation of social skills sheets used during learning.

Data analysis techniques used in this study include validity and reliability tests, prerequisite tests (normality and homogeneity tests), hypnotized gain, hypothesis testing (MANOVA test), and effect size. The MANOVA test was used to determine whether there were differences in the application of STAD cooperative learning to the analytical skills and social skills of students studying science in students both in the experimental class and in the control class. Normalized gain (n-gain score) is used to find out the improvement of analytical skills and social skills. Effect size is used to determine the effect of the application of the STAD cooperative learning model. The magnitude of effect effect size is based on the following categories
Table 3. Interpretation of Effect Size Values

\begin{tabular}{|c|c|c|}
\hline $\begin{array}{l}\text { Cohen's } \\
\text { Standar }\end{array}$ & Effect Size & Percentage (\%) \\
\hline \multirow{13}{*}{ High } & 2,00 & 99,7 \\
\hline & 1,90 & 99,7 \\
\hline & 1,80 & 96,4 \\
\hline & 1,70 & 95,5 \\
\hline & 1,60 & 94,5 \\
\hline & 1,50 & 93,3 \\
\hline & 1,40 & 91,9 \\
\hline & 1,30 & 90 \\
\hline & 1,20 & 88 \\
\hline & 1,10 & 86 \\
\hline & 1,0 & 84 \\
\hline & 0,9 & 82 \\
\hline & 0,8 & 79 \\
\hline \multirow{3}{*}{ Medium } & 0,7 & 76 \\
\hline & 0,6 & 73 \\
\hline & 0,5 & 69 \\
\hline \multirow{5}{*}{ Low } & 0,4 & 66 \\
\hline & 0,3 & 62 \\
\hline & 0,2 & 58 \\
\hline & 0,1 & 54 \\
\hline & 0,0 & 50 \\
\hline
\end{tabular}

(Source: Becker, 2000: 3)

Data analysis techniques on the feasibility of learning both the experimental class and the control class using the analysis of the percentage of the feasibility of learning from the observations of teacher activities.

\section{RESEARCH AND DISCUSSION RESULTS}

Data on the results of the learning achievement were obtained from observations of each learning activity of teachers and students that had been adjusted to the Learning Implementation Plan (RPP) by 2 observers. The results of the percentage of the feasibility of learning using the guideline of conversion percentage of both the experimental class and the control class indicate that learning is done very well. The following are the results of the learning process carried out for 3 consecutive meetings. 
Table 4. Percentage of Learning Execution Control and Experimentation Classes

Average of Three

\begin{tabular}{ccc}
$\begin{array}{c}\text { Science } \\
\text { Learning }\end{array}$ & $\begin{array}{c}\text { Meetings by } 2 \\
\text { Observer } \\
\text { Criteria }\end{array}$ & Criteria \\
\hline $\begin{array}{c}\text { STAD } \\
\text { Cooperative } \\
\text { Model }\end{array}$ & $94,6 \%$ & $\begin{array}{c}\text { Verry } \\
\text { Good }\end{array}$ \\
\hline $\begin{array}{c}\text { Direct } \\
\text { Instruction }\end{array}$ & $86,3 \%$ & $\begin{array}{c}\text { Verry } \\
\text { Good }\end{array}$
\end{tabular}

The analysis ability of students is obtained from the pretest-posttest score. Pretest is done before students are given treatment. While the posttest is done after the students are given treatment, namely the use of STAD cooperative learning models in the experimental class and learning models commonly used by teachers (direct learning) in the control class. Pretest and posttest questions are the same problem in the form of multiple choice questions totaling 20 items that have passed the validity test, reliability test and empirical test first. The results of the pretest and posttest scores in the experimental class and the control class are as follows.

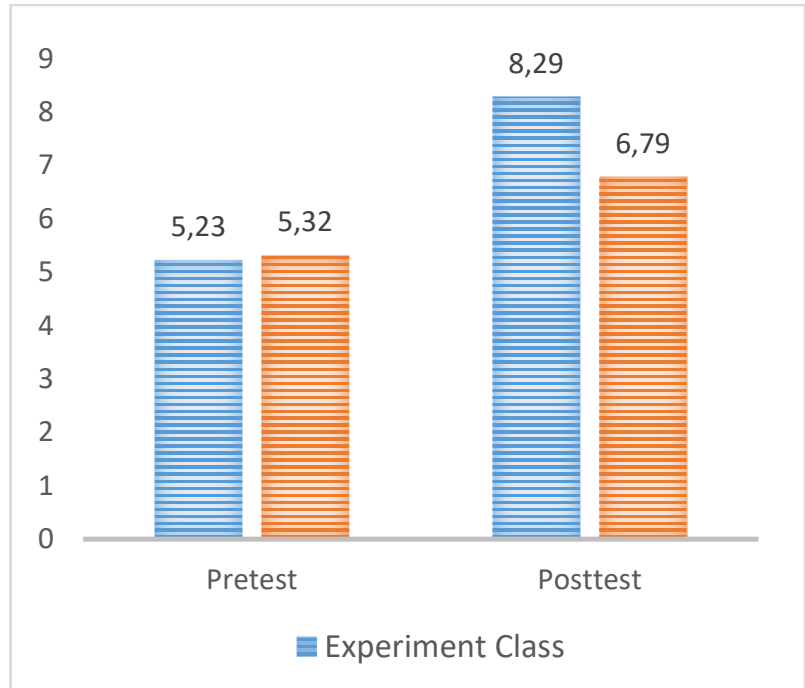

Figure 1. Pretest and Posttest Average Value Diagram

Based on Figure 2 it can be seen that both the experimental class and the control class, an increase in the value of the average pretest to the posttest average value. The increase in value can be known by calculating the n-gain value. The results of the calculation of the n-gain value produces a value of 0,633 with the medium category for the experimental class and 0.294 with the low category for the control class. So that the increase in the value of analytical skills in the experimental class is higher than the control class.

Then the decision making of the influence of the STAD cooperative learning model on the ability of science analysis in students is obtained from the MANOVA test results with a result of 0,000 . So Sig. $0,000<$, then there is a difference in the average value of analytical skills between the experimental class and the control class. The existence of these differences indicates the effectiveness of the application of the STAD type cooperative learning model to the ability of science analysis in students whose magnitude can be known from the results of the calculation of the effect size in the experimental class of 1.76 with a percentage of $96.4 \%$. This shows that the experimental class that uses the STAD type cooperative model has a high effect on students' analytical skills. Whereas in the control class the calculation of effect size is 1.29 with a lower percentage of $90 \%$.

According to (Nikmah 2014: 6) the reason for cooperation being the main pathway in education is one of them because the use of STAD cooperative learning is able to improve student learning outcomes and be able to develop relationships between groups. More effective STAD type cooperative learning models to improve cognitive learning outcomes as measured by students have analytical skills in science learning because STAD cooperative models are seen as active learning processes, because students will learn more through work processes in groups and knowledge sharing.

Students 'social skills are obtained from the pretest-posttest questionnaire and the students' social skills observation. Pretest is done before students are given treatment. While the posttest is done after the students are given treatment, namely the use of STAD cooperative learning models in the experimental class and learning models commonly used by teachers (direct learning) in the control class. The pretest and posttest questions are the same questions in the form of a questionnaire with 30 questions. The results of the pretest and posttest scores in the experimental class and the control class are as follows.

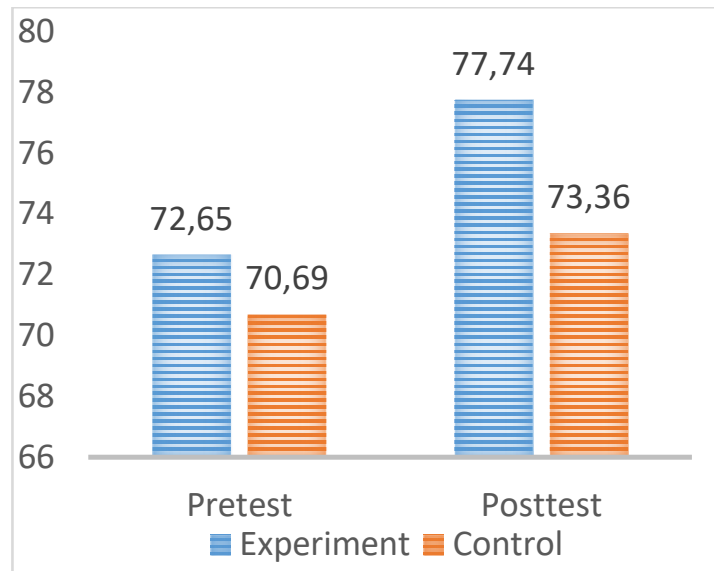

Figure 2. Pretest and Posttest Average Value Diagram 
Based on Figure 2 above, it can be seen that both the experimental class and the control class, an increase in social skills seen in the average pretest and posttest mean scores. The increase in value can be known by calculating the n-gain value. The results of the calculation of the n-gain value produces a value of 0.180 with a low category for the experimental class and 0.109 with a low category for the control class. So that the increase in the value of social skills in the experimental class is higher than the control class.

Then the decision making of the influence of the STAD cooperative learning model on the social ability of science in students is obtained from the MANOVA test results with a result of 0.002 . So Sig. $0,000<$, then there is a difference in the average value of social skills between the experimental class and the control class. The existence of these differences indicates the effectiveness of the application of the STAD type cooperative learning model to the ability of science analysis in students whose effectiveness can be calculated using the analysis of the calculation of effect size according to Cohen's. The result of the large effect size of the effectiveness of the STAD cooperative learning model on students' social skills is 0.92 with a percentage of $82 \%$. This shows that the experimental class that uses the STAD type cooperative model has a high effect on students' analytical skills. Whereas in the control class the calculation of effect size was 0.53 with a lower percentage of $69 \%$ included in medium criteria.

Based on the results of observations of social skills shows both the experimental class and the control class can bring up all indicators of social skills. This causes the learning of the two classes is almost the same, but when viewed from each indicator, it appears that the social skills of the experimental class are higher than the control class, as follows.

$$
\text { EExperiment EControl }
$$

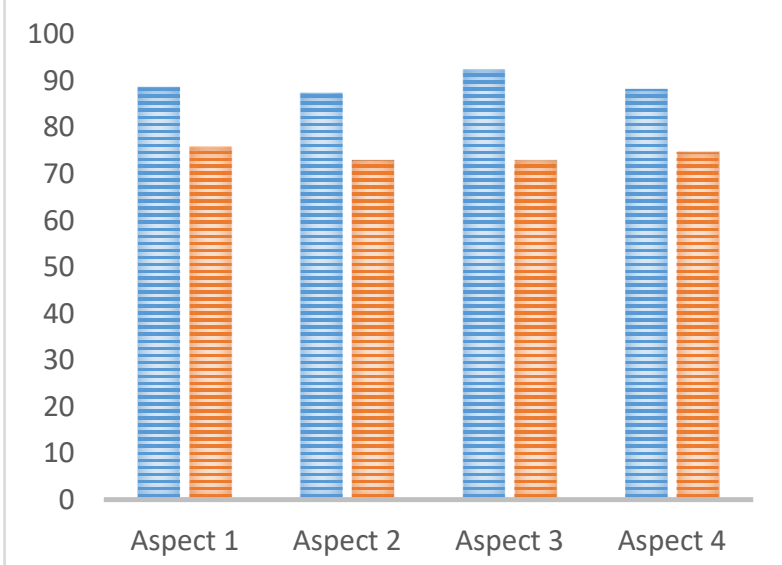

Figure 3. Average Social Skills Value of Each Indicator
Based on the results in Figure 1, it can be seen that in each indicator, the average value of students' social skills in the experimental class is higher than the control class. The experimental class reached an average value of 89.06 including the excellent category, while the control class was 73.75 including the good category. The results of data collection through questionnaire instruments and observation sheets obtained consistent results, namely the social skills of the experimental class students were higher than the control class. in accordance with the opinion of Arens, R. 1. (2008: 5-6) cooperative learning models are developed to achieve the goals of one of them social skills.

The Effectiveness of Student Team Cooperative Dichi (STAD) Cooperative Learning in Science Learning Against Analytical Skills and Social Skills. Decision making of the effectiveness of the STAD cooperative learning model of the analytical skills and social skills of Grade VII students was analyzed using the MANOVA test with the results of the Sig. of 0,000. Therefore Sig. $0,000<$, then there is a significant difference in the STAD cooperative learning model of analytical skills and social skills. This difference indicates the effectiveness of the STAD cooperative learning model of analytical skills and social science skills in grade VII students of SMP N 4 Wonosari.

The STAD cooperative learning model influences the students' analytical skills and social skills which are also stated by Arens, R. 1. (2008: 56 ) that the STAD cooperative learning model is a cooperative learning model that has goals: (1) cognitive learning outcomes, (2) acceptance and diversity, (3) development of social skills.

\section{CONCLUSION}

Based on the results of the research and discussion in chapter IV, it can be concluded that: (1) The STAD type cooperative learning model is effective for improving students' analytical skills in science subjects. (2) STAD type cooperative learning model is effective to improve students' social skills in natural science subjects. (3) The STAD type cooperative learning model is effective for enhancing students' analytical skills and social skills simultaneously on science subjects.

\section{REFERENCES}

Arends, R. I. 2008. Learning to Teach. Belajar untuk Mengajar Jilid 1 Edisi Ke Tujuh Buku Satu Penerjemah: Helly Prajuni Soetjipto dan Mul

Arifin, Zainal. 2011. Evaluasi Pembelajaran. Bandung. PT. Remaja Rosdakarya 
Becker, L. (2000). Effect Size Measure For Two Independent Groups. Jurnal Effect Size Becker, 3.

Djudju, Sudjana. 2007 . Ilmu Dan Aplikasi Pendidikan. Jakarta: Grasindo.

Gull, F. (2015). Effects of Cooperative Learning on Students Academic Achievement. Journal of Education and Learning, 247.
Huda, M. 2012. Model-model Pengajaran dan Pembelajaran. Yogyakarta: Pustaka Pelajar.

Sugiyono. (2015). Metode Penelitian Pendidikan: Pendekatan Kuantitatif, Kualitatif, dan $R \& D$. Bandung: Alfabeta. 